\title{
Early arbuscular mycorrhiza colonization of wheat, barley and oats in Andosols of southern Chile
}

\author{
C. G. Castillo ${ }^{1,3 *}$, F. Puccio ${ }^{1}$, D. Morales ${ }^{1}$, F. Borie ${ }^{2,3}$, and E. Sieverding ${ }^{4}$ \\ ${ }^{1}$ Universidad Católica de Temuco, Facultad de Recursos Naturales, Escuela de Agronomía, Casilla 15-D, \\ Temuco, Chile. ${ }^{2}$ Universidad de La Frontera, Departamento de Ciencias Químicas y Recursos Naturales, \\ Temuco, Chile. ${ }^{3}$ Scientifical and Technological Bioresource Nucleus (BIOREN), Universidad de La Frontera, \\ Casilla 54-D, Temuco, Chile. ${ }^{4}$ University Hohenheim, Institute of Plant Production and Agroecology in the \\ Tropics and Subtropics, Garbenstr. 13, 70599 Stuttgart, Germany. ${ }^{*}$ Corresponding author: ccastill@uct.cl
}

\begin{abstract}
In cereals cultivated in Southern Chilean Andosols, arbuscular mycorrhizal (AM) fungi may play a main role for phosphorus $(\mathrm{P})$ uptake. Because $\mathrm{P}$ acquisition at early growth stages is crucial for cereals, we investigated the development of indigenous AM during the first 45 days after planting of two wheat, barley and oats varieties in two typical Andosols of the region, under plastic house. Minimum temperatures were between $-5^{\circ} \mathrm{C}$ and $+5^{\circ} \mathrm{C}$ at night and maximum between $18^{\circ} \mathrm{C}$ and $30^{\circ} \mathrm{C}$ during day. The results showed that root biomass of all species increased in both soils until 30 days and remained constant thereafter until 45 days. The intensity of AM infection (root area and root biomass infected) was low at 15 days, increased slightly from 15 to 30 days and increased sharply and significantly from 30 to 45 days. Plant species and varieties differed in root biomass formation but not in frequency and intensity of infection with AM structures. Thus, those cereals species and varieties with more root production had higher total mycorrhizal root biomass, and those may potentially benefit more from AM. It is also concluded that during early growth stages cereals invest first into root development and then into AM fungal biomass.
\end{abstract}

Keywords: cereals, physiology, symbiosis, root colonization, root biomass. 


\section{Introduction}

Southern Chile is the main production area of wheat, barley and oats in Chile (ODEPA, 2011). It is well established in literature that the Andosols in the area are low in available nutrients and that phosphorus (P) deficiency can limit wheat production (Pino et al., 2002). Soil acidification due to high rainfall and use of ammonium fertilizers (Mora and Demanet, 1999) further increase the problem of low P availability. It has earlier been postulated that the management of the indigenous arbuscular mycorrhizal (AM) fungi may be a valuable agronomic tool to optimize $\mathrm{P}$ aquisition of cereals by biological means, and thus increase soil productivity and grain yields (Sieverding, 1991). There is no doubt that the AM symbiosis between plant roots and glomeromycotean fungi has its primary importance for P uptake and P supply to plants in particular under edaphic conditions where $\mathrm{P}$ is not easily available (Finlay, 2008). In addition, several other beneficial effects of AM fungi for plants have been reported like improved water relations (Auge, 2004), tolerance of salt stress (Daei et al., 2009) and toxic elements in soils (Karimi et al., 2011). Also, improved root health have been reported always when the AM association is established before root pathogenic or nematode attacks occurred (Pfleger and Linderman, 2002).

We were interested in the early development of $\mathrm{AM}$ in roots of the three cereals due to two main reasons:

a) Plant nutritional studies have shown that the $\mathrm{P}$ acquisition during early cereal growth stages is crucial for their grain production. For example, Elliott et al. (1997) showed in experiments carried out in Australia that any P deficiency until wheat growth stage 30 (tillering finished, start stem elongation, Zadock et al., 1974) will limit yields significantly. P deficiency within 15 days after sowing reduced plant height, root growth and grain yields. Research of the Potash and Phosphorus Institute (Snyder et al., 2003) has also clearly shown in many field research studies in USA and Canada, that early P supply to wheat is important for tillering of the crop and finally for the cereal grain production. Li et al. (2006) have shown that more than $50 \%$ of $\mathrm{P}$ acquisition during the first 36 days of wheat cultivation was by mycorrhiza. Hence, knowing that early P nutrition is so essential in cereals, and knowing that AM is so critical for P nutrition, we decided to systematically study the AM development of each of two varieties of wheat, barley and oat in two representative soils of Southern Chile with their native AM fungal populations.

b) The other reason for being interested in early development of AM in cereals is related to root health. As stated above, AM was found to be of great importance for root health when AM was established first, before root pathogens or nematodes attacked. So, the second reason for the systematic investigation of early AM development in roots of small grain cereals like wheat, barley and oat was whether there are differences between cereal species and varieties in early AM development. This information may at a later stage be of importance for "rhizosphere health" studies in cereals.

AM establishment and root colonization of cereals is known to depend on a) the AM fungi present in the soil and on the germination potential/stimulation of infective fungal propagules (Jeffries et al., 2003); b) the susceptibility of the cereal species and varieties to get infected by AM fungi (Boyetchko and Tewari, 1995) 
where also genetical recognition factors are involved (Gadkar et al., 2001; Balestrini and Lanfranco, 2006), and c) the soil edaphic and biotic conditions and characteristics, like nutrient status, $\mathrm{pH}$, water holding capacity, aeration, organic matter content (Medina and Azcón, 2010), as well as the presence or absence of other rhizosphere and soil microorganisms (Welc et al., 2010). The interactions of these three major components, which influence the establishment of the symbiosis, are rather complex but at the final end the colonization levels within the root tissue are the result of these interactions. So, in the current study we investigated the results of such interactions by measuring the AM infection frequency and intensity in roots, and compared them with shoot and root development.

\section{Materials and methods}

Pot experiments were carried out in a non-heated plastic house, at the Universidad Catolica de Temuco, during July and August 2010. This is the habitually time when cereals are normally planted, in the field, in Southern Chile. Air temperatures in this plastic house were between $-5^{\circ} \mathrm{C}$ and $5^{\circ} \mathrm{C}$ during night as minimum and maximum between $18^{\circ} \mathrm{C}$ and $30^{\circ} \mathrm{C}$ during day time (Figure 1).

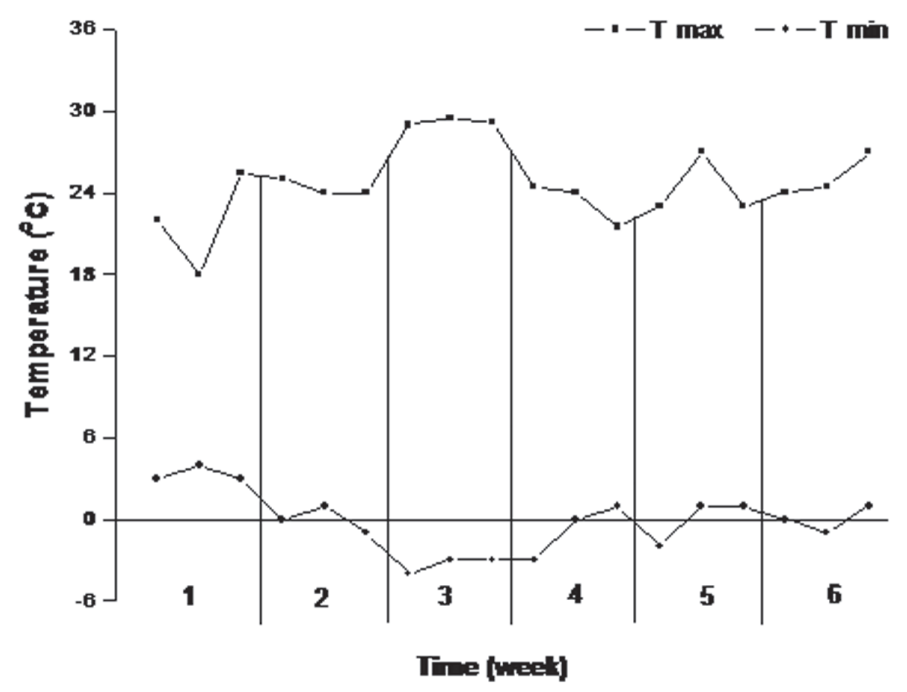

Figure 1. Minimum and maximum air temperatures in plastic house during the time of the experiment.

Two soils were used in the assay, being both typical Andosols for Southern Chile. One soil was from the Agricultural Experimental Station Pillanlelbún of the Universidad Católica de Temuco, Comuna de Lautaro and the other from a field site near Cunco (Table 1). The soil from Pillanlelbún had been cultivated with potato before our use, while the other soil had cereals for the past years before use in the experiment. Soils differed in available P (Olsen and Sommer, 1982) and in organic matter content (Walkley and Black, 1934). Soil $\mathrm{pH}$ (measured in soil:water using 1:2.5 ratio) was between $\mathrm{pH} 5.6$ and 6.0. 
Table 1. Soils used in bioassays.

\begin{tabular}{lcccccc}
\hline Soil & Location & Code & Coordinates & $\begin{array}{c}\mathbf{p H} \\
\text { (in water) }\end{array}$ & $\begin{array}{c}\text { Olsen-P } \\
\left(\mathbf{m g ~ k g}^{-1}\right)\end{array}$ & $\begin{array}{c}\text { Organic } \\
\text { matter }(\%)\end{array}$ \\
\hline Temuco Serie & Pillalelbún & $\mathrm{S} 1$ & $38^{\circ} 62^{\prime} ; 72^{\circ} 46^{\prime}$ & 5.6 & 14.6 & 26.5 \\
Cunco Serie & Cunco & $\mathrm{S} 2$ & $38^{\circ} 55^{\prime} ; 72^{\circ} 02^{\prime}$ & 6.0 & 35.3 & 18.5 \\
\hline
\end{tabular}

Values are averages of three replicates

Soils were collected in the field from a $5-20 \mathrm{~cm}$ depth. They were sieved and homogenized by passing through a sieve with $0.5 \mathrm{~cm}$ mesh opening; $250 \mathrm{~mL}$ soil was filled into $300 \mathrm{~mL}$ plastic pots. Two different wheat, barley and oats varieties were used in the study (Table 2); these varieties are widely used in the region of La Araucanía, the Center of Southern Chilean cereal production. Seeds were superficially disinfected and then pre-germinated in plastic Petri dishes. One seed per pot was planted just after radicle germination. This was done to make sure that homogenously germinated seed was planted in all pots. During the time of the experiment no fertilizers were added. Soil humidity was maintained at water holding capacity of the soils. Such humidity levels are common during the winter and early spring time also in the field.

Table 2. Cereal species, varieties and growth habits of cereals planted.

\begin{tabular}{lclc}
\hline Cereal species & Varieties & Code & Growth habit \\
\hline Triticum aestivum L. & "Kumpa-INIA" & $\mathrm{CV}-1$ & Winter variety \\
& "Bakán-Baer" & $\mathrm{CV}-2$ & Alterative variety \\
Hordeum vulgare L. & "Sebastián-Baer" & $\mathrm{CV}-1$ & Spring variety \\
& "Barke-Baer" & $\mathrm{CV}-2$ & Spring variety \\
Avena sativa L. & "Pepita-Baer" & $\mathrm{CV}-1$ & Alternative variety \\
& "Supernova-INIA" & $\mathrm{CV}-2$ & Alternative variety \\
\hline
\end{tabular}

* Alternative varieties can be planted in Southern Chile in fields during any time of winter through spring

Of each plant variety, twelve pots were sown. Four pots each were harvested 15 days after planting (DAP), for oats at $21 \mathrm{DAP}(\mathrm{H} 1), 30 \mathrm{DAP}(\mathrm{H} 2)$ and 45 DAP (H3). Second and third harvests corresponded to plant growth stages 1.12 and 1.13 (two and three leaves unfolded, Zadock et al., 1974). First harvest of oats was delayed as earlier own investigations had shown no mycorrhizal root infection at 15 DAP.

For each harvest, plant shoots were cut at ground level and the fresh weight was determined. Roots were carefully washed free from soil and fresh weight was established. A subsample of fresh root 
material was taken randomly after the whole root sample had been cut into about $1 \mathrm{~cm}$ long segments. This subsample was used for determination of AM colonization. AM fungal structures in roots were stained with $0.05 \%$ trypan blue at $60^{\circ} \mathrm{C}$ for $5 \mathrm{~min}$ in a water bath (Phillips and Hayman, 1970) after heating in $2.5 \% \mathrm{KOH}$ at $60^{\circ} \mathrm{C}$ for $12 \mathrm{~min}$, rinsing then in a few changes of water, and acidifying the roots in $1 \%$ hydrochloric acid at room temperature for $1 \mathrm{~h}$. The stained root segments were stored in distilled water and $4^{\circ} \mathrm{C}$ until they were used for slide preparation. Thirty root segments (about $1 \mathrm{~cm}$ long) of each treatment were mounted on three slides in a polyvinyl alcohol-lactic acid-glycerol solution (Koske and Tessier, 1983) and examined at 100-400x magnification under a Olympus YS100 light microscope. Frequency of mycorrhizal infection (F \%) was assessed by relating the number of infected $1-\mathrm{cm}$ root segments (no) to the total number $1-\mathrm{cm}$ root segments observed (N): F\% = $100(\mathrm{~N}-$-no) / N. Intensity of AM infection in the root cortex was determined by the five-class classification system following the method described by Trouvelot et al. (1986). This measurement is based on the infection (M\%) in each root segment using values from 0 to 5 . Numbers indicate the proportion of root cortex colonized by the fungus: $0=$ without colonization; $1=$ colonization trace; $2=$ less than $10 \% ; 3=$ from 11 to $50 \% ; 4=$ from 51 to $90 \%$; and $5=$ more than $90 \%$ of the volume of root segment occupied by the fungus. M\% was estimated by the following equation: $\mathrm{M} \%=(95 \mathrm{n} 5+$ $70 \mathrm{n} 4+30 \mathrm{n} 3+5 \mathrm{n} 2+\mathrm{n} 1) / \mathrm{N}$, where $\mathrm{n} 5, \mathrm{n} 4, \mathrm{n} 3, \mathrm{n} 2$, and $\mathrm{n} 1$ are the number of fragments in the respective categories 5, 4, 3, 2, and 1 (Alarcón and Cuenca, 2005). The root biomass infected with mycorrhiza was calculated by multiplying the root fresh weight with $\mathrm{M} \%$.

\section{Statistical analysis}

The data were analyzed using mean values and standard deviations which are shown in the graphs within the Results section.

\section{Results}

\section{Triticum aestivum $\mathrm{L}$.}

Shoot and root fresh weight increased until 30 days after planting (DAP) and remained almost constant thereafter (Figure 2) in both soils. Biomass production was somewhat higher in the Pillanlelbún soil. Wheat var. "Bakán" (CV-1) had a higher production than var. "Kumpa" (CV-2). Frequency of AM infected roots was high between about $15-50 \%$ at $15 \mathrm{DAP}$ and increasing to more than $30-70 \%$ at 30 DAP and 45 DAP with little differences between the varieties. Intensity of AM infection was low until 30 DAP and increased thereafter sharply in both soils and both varieties. There were little differences between varieties. However, when calculating the infected root biomass, it was evident that var. "Bakán" had more infection than var. "Kumpa", but without much differences between soils (Figure 2). 

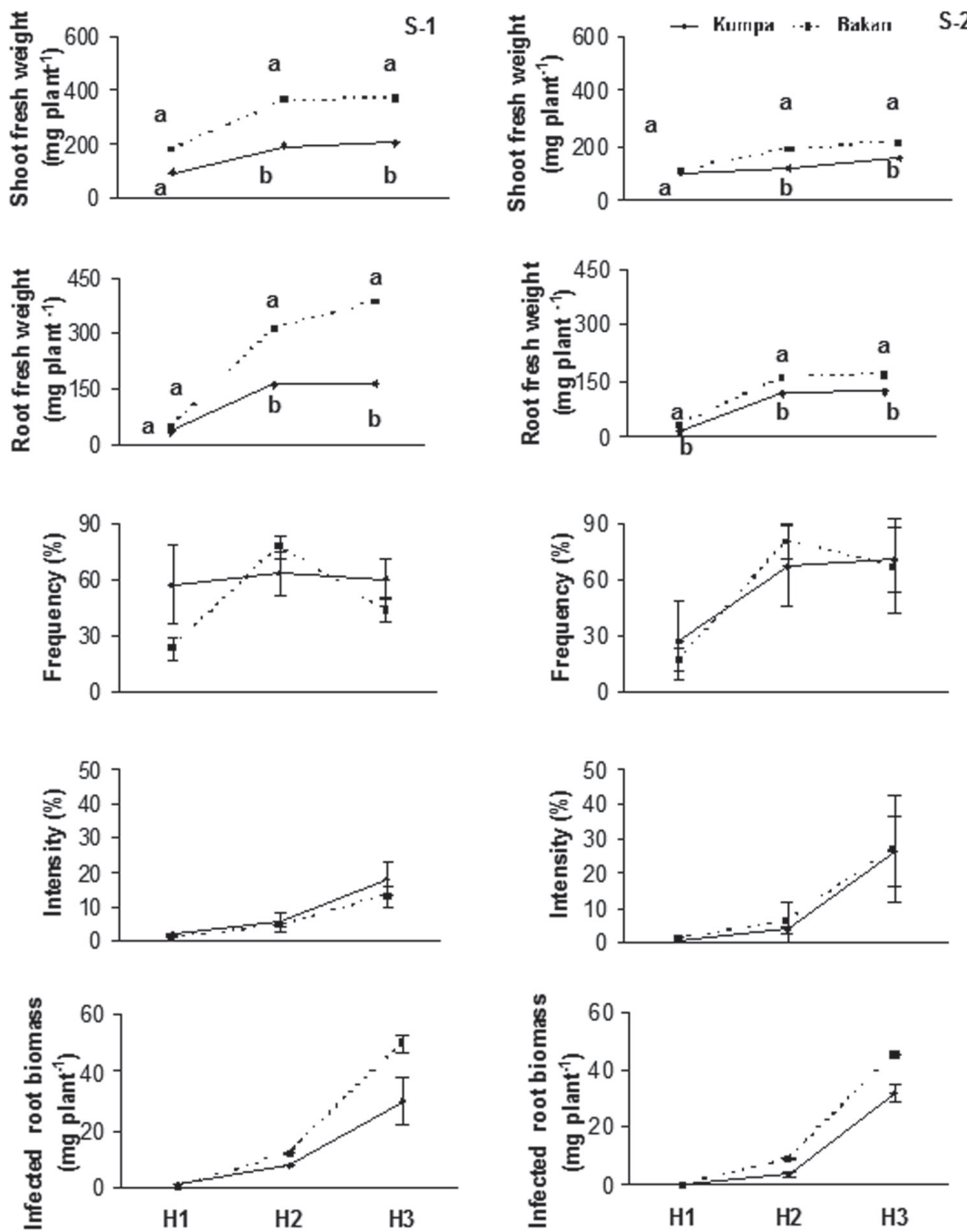

Harvest

Harvest

Figure 2. Plant growth parameter (shoot and root fresh weight) and mycorrhizal colonization parameters (frequency of infection, infection intensity, and infected root biomass) in wheat var. "Kumpa" (CV-1) and var. "Bakán" (CV-2) at 15 days after planting (DAP, H1), 30 DAP (H2), and 45 DAP (H3) in two Andosols: Pillalelbún (S-1) and Cunco (S-2). Bars indicate standard deviation of 4 replicates.

Hordeum vulgare L.

Growth of barley varieties followed about the same pattern as wheat varieties over time (Figure 3). While biomass production of var. "Sebastián" was clearly higher in the Pillanlelbún soil, no differences were found between varieties in the Cunco soil. Also, there was little increase in biomass over the growth period 
in Cunco soil. Frequency of AM root infection was between 30 and $80 \%$ with var. "Sebastián" and infection frequency increased in both soils from 15 to 30 DAP. Little or no response was found over time in infection frequencv with var. "Barke". Intensitv of AM
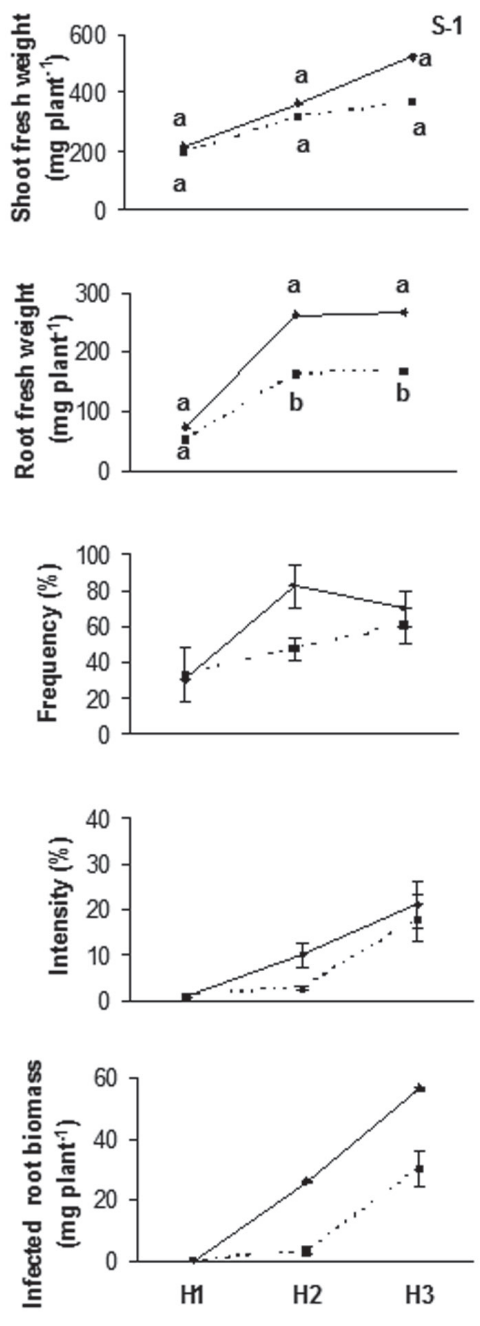

Harvest infection in Cunco soil was similar as with wheat but in Pillanlelbún soil var. "Sebastián" increased infection intensity linearly over time, while in var. "Barke" infection intensity and infected biomass was low at 15 and 30 davs before it increased (Figure 3 ).
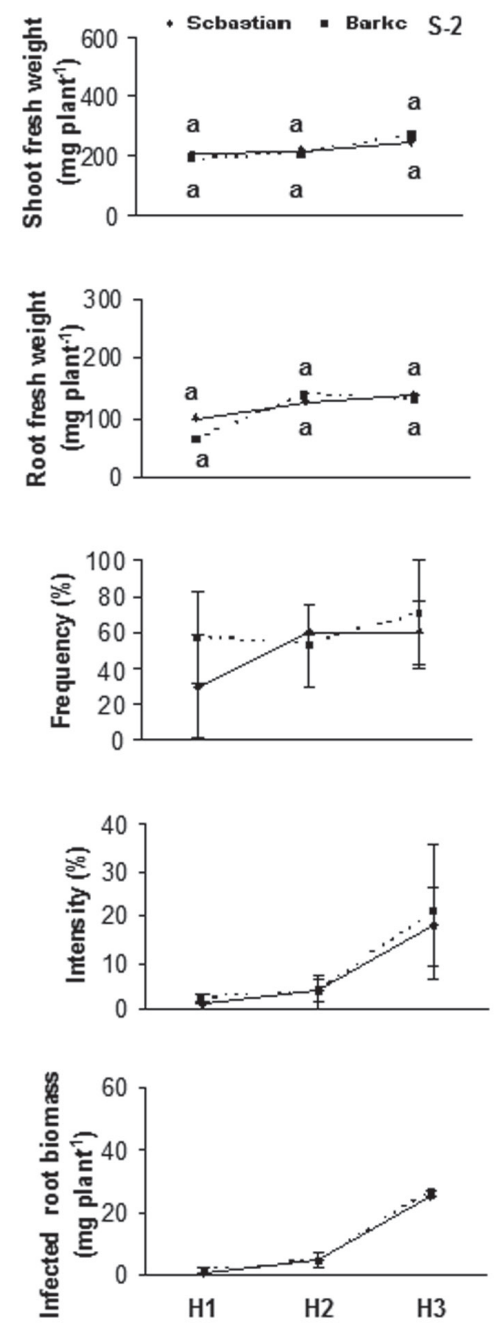

Harvest

Figure 3. Plant growth parameter (shoot and root fresh weight) and mycorrhizal colonization parameters (frequency of infection, infection intensity, and infected root biomass) in barley var. "Sebastián" (CV-1) and var. "Barke" (CV-2) at 15 days after planting (DAP, H1), 30 DAP (H2), and 45 DAP (H3) in two Andosols: Pillalelbún (S-1) and Cunco (S-2). Bars indicate standard deviation of 4 replicates. 


\section{Avena sativa L.}

Increase of oats growth over time depended on the variety and soil (Figure 4). Less increase of biomass over time was found with var. "Supernova" than with var. "Pepita". In Cunco soil var. "Pepita" increased biomass more over time than in Pillanlelbún soil. While frequency of AM root infection increased somewhat with time in Pillanlelbún soil, and more with var. "Supernova" than with "Pepita", frequency of infection was at around $30 \%$ only in Cunco soil at all timings and with both varieties. Infection intensity and infected root biomass were very low at 21 and $30 \mathrm{DAP}$, and increased considerably until 45 DAP. Differences between varieties were little except that infected root biomass in Cunco soil remained low with var. "Supernova" at 45 DAP (Figure 4).
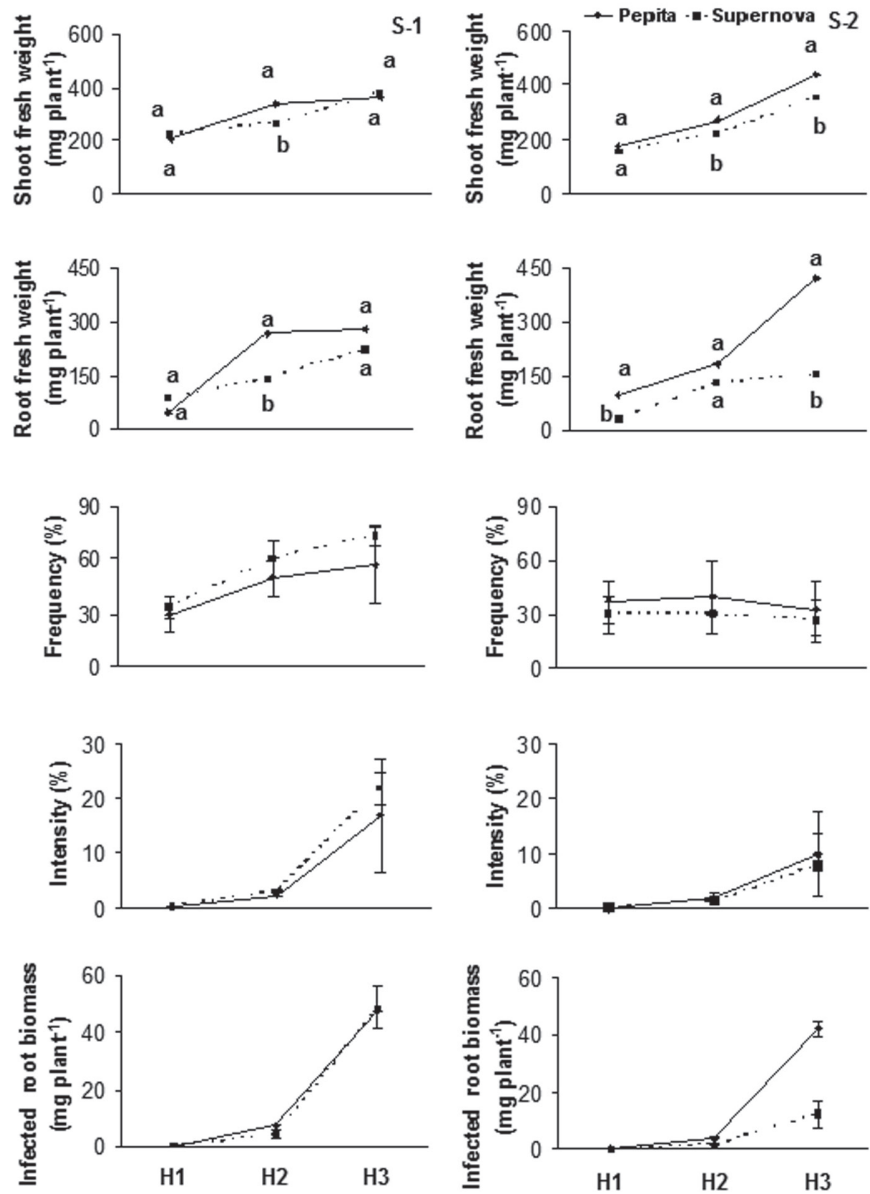

Harvest

Harvest

Figure 4. Plant growth parameter (shoot and root fresh weight) and mycorrhizal colonization parameters (frequency of infection, infection intensity, and infected root biomass) in oats var. "Pepita" (CV-1) and var. "Supernova" (CV-2) at 21 days after planting (DAP, H1), 30 DAP (H2), and 45 DAP (H3) in two Andosols: Pillalelbún (S-1) and Cunco (S-2). Bars indicate standard deviation of 4 replicates. 


\section{General plant species effect}

Oats, followed by barley, produced most biomass on average of all varieties and soils. Wheat had significant less biomass production and little increase over time (Figure 5). When wheat, barley and oats were compared as main factors for AM root infection (Figure 5), it was clear that frequency of root infection was similar with all three species at the first harvest and increased until 30 DAP without further increase until 45 DAP. However, in general it appears that wheat had highest AM infection frequency, followed by barley and oats which presented the lowest frequency. Intensity of infection was low for all three species at first and second harvest and increased thereafter sharply and significantly at the third harvest. There, no difference in infection intensity was found between wheat and barley but it appears that oats had always lower infection intensities. Interestingly, all three plant species had same infected root biomass at each harvest and infected root biomass increased for the three species in the same way over time (Figure 5).

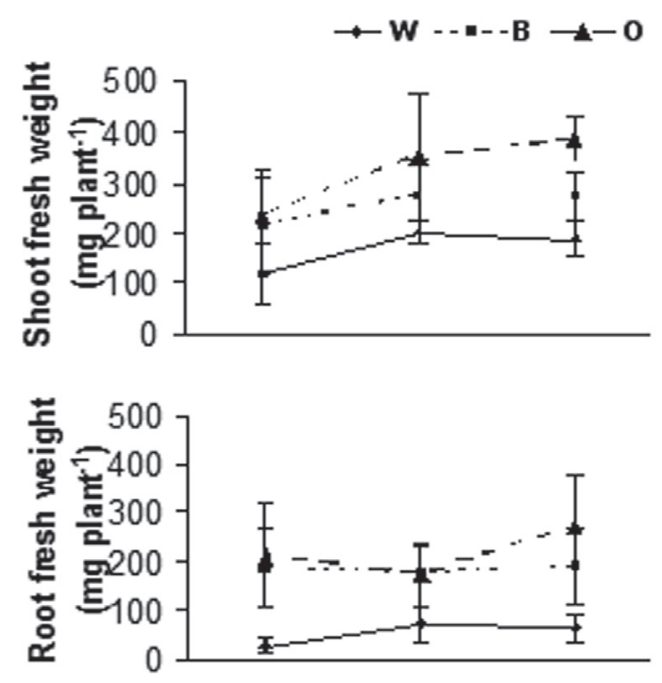

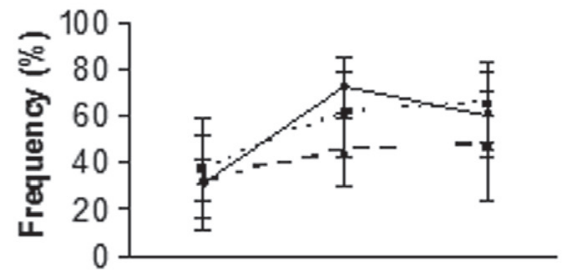
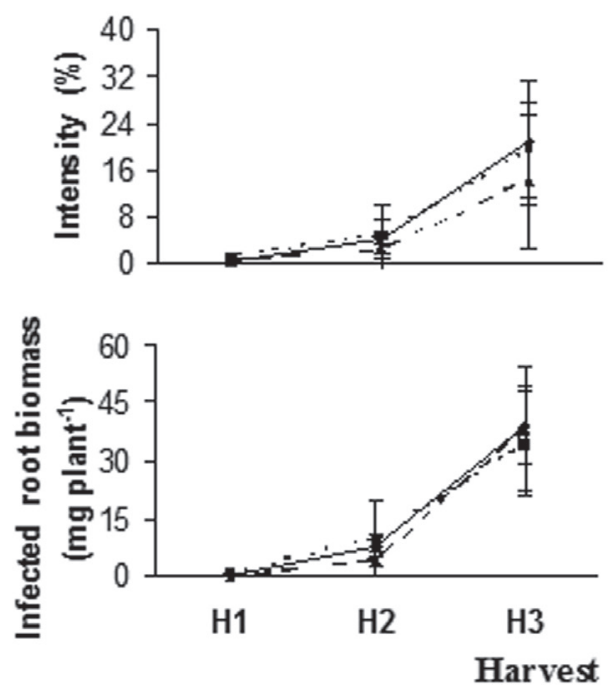

Figure 5. General main effect of plant species wheat $(\mathrm{W})$, barley (B) and oats $(\mathrm{O})$ on growth parameter (shoot and root fresh weight) and mycorrhizal colonization parameters (frequency of infection, infection intensity, and infected root biomass) at first harvest (15 or 21 days after planting DAP; H1), 30 DAP (H2) and 45 DAP (H3). Means of two varieties and two soils per crop are presented with standard deviation. 


\section{General soil effect}

Biomass production was tentatively better in soil from Pillanlelbún, but deviation between plant species was great (Figure 6). When the two soils were compared for frequency of AM infection, it was clear that infection increased from first to second harvest and remained constant thereafter. Variation between plants was high (Figure 6). Root infection intensity developed over time exactly in the same way in both soils. The infection intensity was lower than $5 \%$ until second harvest, and increased to more than $15 \%$ at third harvest. Infected root biomasses increased over time, and sharply from 30 to 45 DAP. The infected root biomass was somewhat higher in the Pillanlelbún soil.

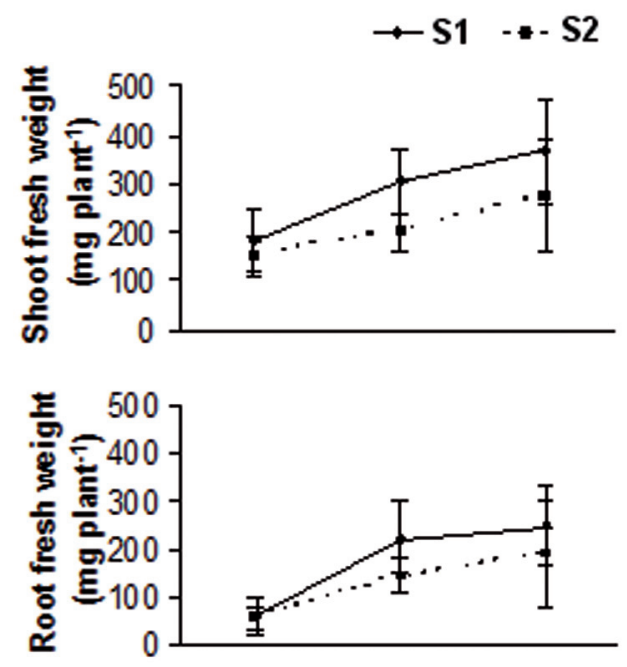

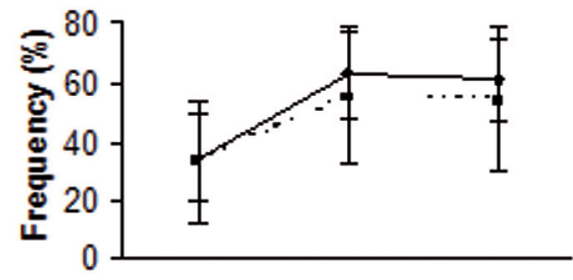
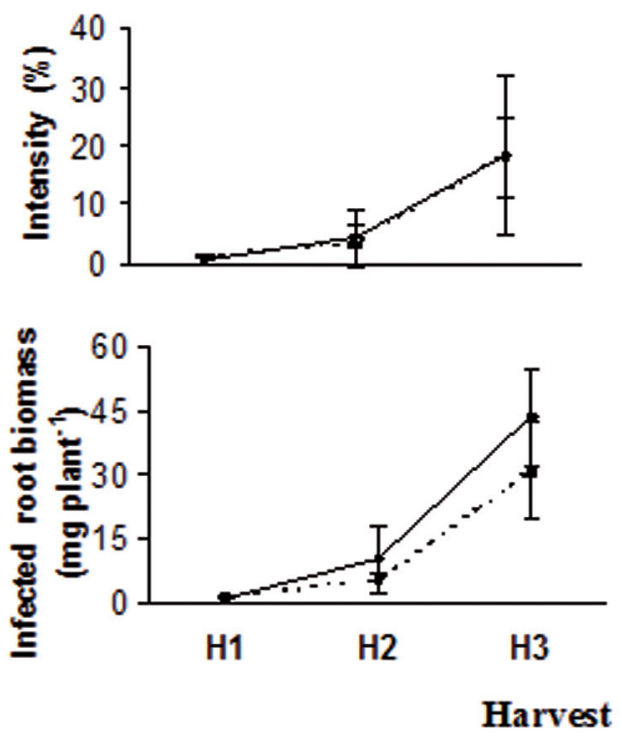

Figure 6. General main effect of soils (S1: Pillanlelbún, S2: Cunco) on growth parameter and mycorrhizal colonization parameters (frequency of infection, infection intensity, and infected root biomass) at first harvest (15 or 21 days after planting, DAP; H1), 30 DAP (H2) and 45 DAP (H3). Means of three cereal species and each two varieties are presented with standard deviation. 


\section{Discussion}

It has been well established in literature that the early development of AM in plant roots follows a sigmoidal function with typically 3 phases: a lag, an exponential and a plateau infection phase (Allen, 2001). We had similar pattern when we used percentage intensity of AM root infection and infected root biomass but plateau phase was not reached in the time of the experiment. Frequency of root infection followed more the pattern of root biomass production which means an increased frequency over time in the same way as root biomass increased.

Considering the main effects of plant species and soil, it appears that shoots and root biomass of all species increased up to $30 \mathrm{DAP}$ and remained then constant. In contrast, AM root infection intensity and infected root biomass was generally low until 30 days after sowing and then increased sharply until 45 DAP. Hence it appears that the plant first invested in root biomass production before photosynthetic products were used for AM fungal development and AM fungal biomass in roots. Such relationships sound logical from a physiological point of view and carbon and nutrient sink-source relations have been described (Podila and Douds, 2000), but this has not been shown in such a way in earlier studies with wheat, barley and oats, as far as we know.

Overall, frequency of AM infection was higher in wheat plants than in barley and oats (Figure 5 at last harvest), and the percentage intensity of root infection suggested that oats was less infected than the other two cereals. However, the root biomass with mycorrhizal structures was with 35-40 mg similar in all the three cereal species while the total root fresh biomass varied greatly between the cereal species from 90 to $280 \mathrm{mg}$ per plant. This result could give reason to conclude that either the cereal species genetically control the fluxes of photosynthates to generate either more root or fungal biomass, or that AM fungi are simply limited in production of more biomass during this early plant growth stage under the given climatic conditions. A closer look at the variety level shows (Fig. $2-4$ ) that those varieties with more root production had in general also more infected root biomass. We can assume that root biomass was correlated with root length and that through more intensive soil exploration more roots became infected by AM fungal propagules which were evenly distributed in the homogenized soils. Sieverding (1991) found such correlations with other plant species, like cassava. Thus, cereal genotypes with more roots can theoretically make more effective use of native mycorrhizal populations. In this study we did not investigate the nutrient acquisition of the cereal genotypes and further studies have to clarify which amounts of nutrients are taken up by AM fungal biomass and which proportion by the root itself. Another aspect is also obvious from the results: if we assume that more AM occupied root biomass is important for root health and root protection against pathogens, then wheat roots are relatively more protected than oats or barley roots, as wheat had the smallest non-infected to infected root biomass ratio.

Soil characteristics may affect plant development and early AM development (Figure 6). Cunco soil had higher available $\mathrm{P}$ than the soil from Pillanlelbún, and this may be the reason why the total amount of AM infected root biomass was tentatively less in the Cunco soil. Such negative effects of higher available $\mathrm{P}$ contents in soils on AM development were clearly established before (Ning and Cumming, 2001; Li et al., 2006). However, from our results we cannot explain why oats reacted in biomass production different than wheat and barley in the two soils (Figures 2, 3, 4). It is not clear yet whether the lower biomass production of wheat and barley in Cunco than in Pillanlelbún soil was a result of reduced or retarded AM development in the Cunco soil, but this should be investigated in fu- 
ture. It may be that the differential development of the varieties was related to their genetic ability to produce more shoot and root biomass shortly after germination at the given climatic conditions, in these soils. It was clear from the results that those varieties which had higher shoot biomass, had also higher root biomass production. However, even though the root biomasses differed between the varieties, the two varieties of each of the investigated cereal species did not differ in the intensity of root infection. This is interesting as it could mean that under the test conditions, the susceptibility of the varieties to AM infection was similar, and that genetical differences between the varieties did not influence the mycorrhizal infection process. The subjects of susceptibility and compatibility of AM fungi with plant varieties was and currently still is a matter of great scientific interest (Boyetchko and Tewari, 1995; Garg and Chandel, 2010). Succesptibility studies using molecular biological tools could be of much interest to explain partly the early AM development process in cereals, in future.

\section{Conclusions}

Little information is available in literature about early arbuscular mycorrhizal (AM) development in wheat, barley and oats. It is also difficult to compare our results with those presented in literature (e.g. Rubio et al., 1991) where slightly different AM parameters and methods were applied to investigate AM. We conclude from the current study that both AM infection intensity and root biomass development are important parameters for studying the early AM development in cereals. Plants invest photosynthesis products preferably in root biomass (up to 30 days after planting) before AM biomass increases. Early development of fungal biomass in roots may be primarily influenced by root growth patterns in a given soil. As the aim of this study was not to investigate $\mathrm{P}$ acquisition at the early cereal growth stages and further research needs to show if it is beneficial for P uptake and root health to accelerate and improve the early mycorrhizal infection processes in cereals by means of agronomic inputs such as seed treatment with natural products or with chemicals.

\section{Acknowledgements}

This study was financed by FONDECYT Project 11090014, from Comisión Nacional de Investigación Científica y Tecnológica, CONICYT, Chile.

\section{References}

Alarcón, C., Cuenca, G. 2005. Arbuscular mycorrhizal in coastal sand dunes of the Paraguaná, Península Venezuela. Mycorrhiza 16, 1-9.

Allen, M.F. 2001. Modeling arbuscular mycorrhizal infection: is \% infection an apropiate variable? Mycorrhiza 10, 255-258.

Auge, R.M. 2004. Arbuscular mycorrhizae and soil/ plant water relations. Can. J. Soil Sci. 84, 373381.

Balestini, R., Lanfranco, L. 2006. Fungal and plant gen expression in arbuscular mycorrhizal symbiosis. Mycorrhiza 16, 509-524.

Boyetchko, S.M., Tewari, J.P. 1995. Susceptibility of barley cultivars to vesicular-arbuscular mycorrhizal fungi. Can. J. Plant Sci. 75, 269-275.

Daei, G., Ardekani, M.R., Rejali, F., Teimuri, S., Miransari, M. 2009. Allevation of salinity stress on wheat yield, yield components, and nutrient uptake using arbuscular mycorrhizal fungi under field conditions. J. Plant Physiol. 166, 617-625.

Elliot, D.E., Reuter, D.J., Reddy, G.D., Abbott, R.J. 1997. Phosphorus nutrition of spring wheat (Triticum aestivum L.). 1. Effects of phosphorus supply on plant symptoms, yield, components of yield, 
and plant phosphorus uptake. Australian J. Agric. Res. $48,855-868$.

Finlay, R.D. 2008. Ecological aspects of mycorrhizal symbiosis: with special emphasis on the functional diversity of interactions involving the extraradical mycelium. J. Exp. Bot. 59, 1115-1126.

Gadkar, V., Schwartz, R.D., Kunik, T., Kapulnik, Y. 2001. Arbuscular mycorrhizal fungal colonization. Factors involved in host recognition. Plant Physiol. 127, 1493-1499.

Garg, N., Chandel, S. 2010. Arbuscular mycorrhizal networks: process and functions. A review. Agron. Sustain. Dev. 30, 581 - 599.

Jeffries, P., Gianinazzi, S., Perotto, S., Turnau, K., Barea, J.M. 2003. The contribution of arbuscular mycorrhizal fungi in sustainable maintenance of plant health and soil fertility. Biol. Fertil. Soils 37, 1-16.

Karimi, A., Khodaverdiloo, H., Sepehri, M., Sadaghiani, M.R. 2011. Arbuscular mycorrhizal fungi and heavy metal contaminated soils. African J. Microbiol. Res. 5, 1571-1576.

Koske, R.E., Tessier, B. 1983. A convenient, permanent slide mounting medium. Mycol. Soc. Amer. Newslett. 34, 59.

Li, H., Smith, S.E., Holloway, R.E., Zhu, Y., Smith F.A. 2006. Arbuscular mycorrhizal fungi contribute to phosphorus uptake by wheat grown in a phosphorus-fixing soil even in the absence of positive growth responses. New Phytologist 172, 536-543.

Medina, A., Azcón, R. 2010. Effectiveness of the application of arbuscular mycorrhiza fungi and organic amendments to improve soil quality and plant performance under stress conditions. J. Soil Plant Nutr. 10: 354-372.

Mora, M.L., Demanet, R.F. 1999. Uso de enmiendas calcáreas en suelos acidificados. Frontera Agrícola 5, 43-58.
Ning, J., Cumming, J.R. 2001. Arbuscular mycorrhizal fungi alter phosphorus relations of broomsedge (Andropogon virginicus L.) plants. J. Exp. Bot. 52, 1883-1891.

ODEPA. 2011. Estadísticas de cultivos esenciales. Información de superficie sembrada, producción y rendimientos anuales. Disponible en http://www. odepa.gob.cl/menu/MacroRubros.action;jsessioni $\mathrm{d}=$ 0D0B329EAB4A81C30E665715BEB3B98F? rubro $=$ agricola\&reporte $=$.

Olsen, S.R., Sommers, L.E. 1982. Phosphorus. In: Methods of Soil Analysis. Part 2. $2^{\text {nd }}$ ed. Page et al. (Eds.). pp. 403-430. Agron. Monogr. 9. ASA and SSSA, Madison, Wiscosin, USA.

Pfleger, F.L., Linderman, R.G. 2002. Mycorrhizae and Plant Health. APS Press. The American Phytopathological Society, St. Paul Minisota. 344 p.

Phillips, J., Hayman, D. 1970. Improved procedures for cleaning roots and staining parasitic and vesicular arbuscular mycorrhizal fungi for rapid assessment of infection. Trans. British Mycol. Soc. $55,158-161$.

Pino, I., Parada, A.M., Zapata, F., Navia, M., Luzio, W. 2002. Comparative study of P uptake and utilization from $\mathrm{P}$ fertilizers by Chilean wheat genotypes in volcanic ash soils. In: Assessment of Soil Phosphorus Status and Management of Phosphatic Fertilisers to Optimise Crop Production. International Atomic Energy Agency, IAEATECDOC-1272. pp. 156-163. Vienna.

Podila, G.K., Douds, D.D. 2000. Current Advances in Mycorrhizae Research. APS Press. The American Phytopathological Society, St. Paul Minisota. $193 \mathrm{p}$.

Rubio, R., Castillo, C., Moraga, E., Borie, F. 1991. Algunos parámetros fisiológicos de cuatro variedades de trigo de primavera (Triticum aestivum L.) en simbiosis con hongos de las micorrizas 
vesículo-arbusculares. Agricultura Técnica 51, 151-158.

Sieverding, E. 1991. Vesicular-Arbuscular Mycorrhiza Management in Tropical Agrosystems. GTZSchriftenreihe No. 224. Hartmut Bremer Verlag, Friedland, Germany.

Snyder, C.S., Reetz, H.F., Bruulsema, T.W. 2003. Phosphorus nutrition of wheat - optimize production. NEWS and VIEWS Sept 2003. Potash and Phosphate Institute, Norcross, GA, USA.

Trouvelot, A., Kough, J.L., Gianinazzi-Pearson, V. 1986. Mesure du taux de mycorhization VA d'un système radiculaire. In: Gianinazzi-Pearson, V., Gianinazzi, S. (Eds.). Physiological and Genetical
Aspects of Mycorrhizae. INRA Press, Paris. pp. 217-221.

Walkley, A., Black, I.A. 1934. An examination of Degtjareff method for determining soil organic matter and a proposed modification of the chromic acid titration method. Soil Sci. 37, 29-37.

Welc, M., Ravnskov, S., Kieliszewska-Rokicka, B., Larsen, J. 2010. Suppression of other soil microorganisms by mycelium of arbuscular mycorrhizal fungi in root free soil. Soil Biol. Biochem. 42, 1534-1540.

Zadock, J.C., Chang, T.T., Konzak, C.F. 1974. A decimal code for growth stages of cereals. Weed Res. $14,415-421$. 